Supporting Information

\title{
Mechanism of the $\mathrm{H}_{2}$ Effect on $\mathrm{NH}_{3}$-Selective Catalytic Reduction over $\mathrm{Ag} / \mathrm{Al}_{2} \mathrm{O}_{3}$ : Kinetic and Diffuse Reflectance Infrared Fourier Transform Spectroscopy Studies
}

Guangyan Xu $u^{\dagger}$, Jinzhu Ma ${ }^{\dagger, \star \S}$, Lian Wang ${ }^{\dagger}$, Zhihui Lv $^{\dagger, \S}$, Shaoxin Wang ${ }^{\dagger}$, Yunbo $Y u^{*, \dagger, \downarrow,}$, Hong He $e^{*, \dagger, \ddagger \S}$

† State Key Joint Laboratory of Environment Simulation and Pollution Control, Research Center for Eco-Environmental Sciences, Chinese Academy of Sciences, Beijing 100085, China

* Center for Excellence in Regional Atmospheric Environment, Institute of Urban Environment, Chinese Academy of Sciences, Xiamen 361021, China

${ }^{\S}$ University of Chinese Academy of Sciences, Beijing 100049, China

Corresponding Author

Yunbo Yu *E-mail: ybyu@rcees.ac.cn

Hong He *E-mail: honghe@rcees.ac.cn 


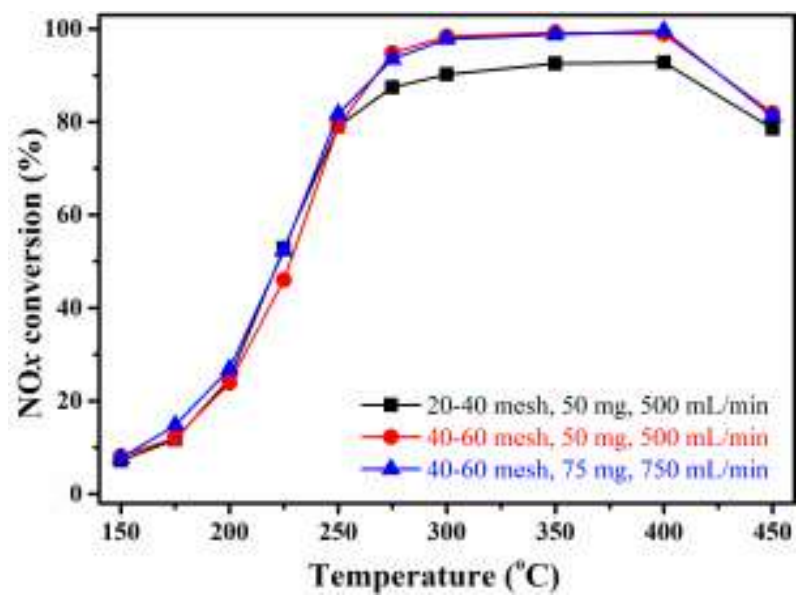

Figure S1. $\mathrm{NO} x$ conversion over $\mathrm{Ag} / \mathrm{Al}_{2} \mathrm{O}_{3}$ during $\mathrm{H}_{2}-\mathrm{NH}_{3}-\mathrm{SCR}$ at different gas flow rates and with different particle size. Feed composition: 500 ppm NO, $520 \mathrm{ppm} \mathrm{NH}_{3}$, 5\% $\mathrm{O}_{2}, 1500$ ppm $\mathrm{H}_{2}$, and $\mathrm{N}_{2}$ balance. GHSV: $450000 \mathrm{~h}^{-1}$. 

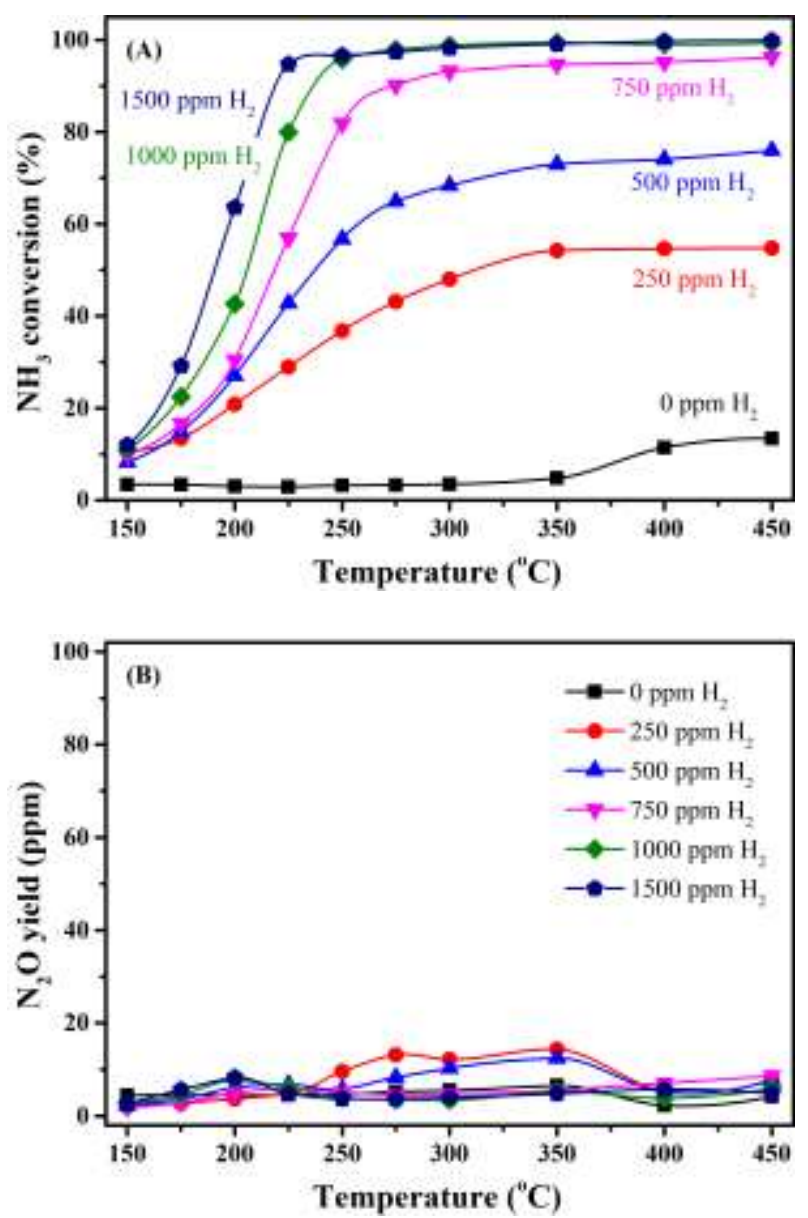

Figure S2. $\mathrm{NH}_{3}$ conversion (A) and $\mathrm{N}_{2} \mathrm{O}$ yield (B) over $\mathrm{Ag} / \mathrm{Al}_{2} \mathrm{O}_{3}$ during $\mathrm{H}_{2}$ assisted $\mathrm{NH}_{3}$-SCR with various amount of $\mathrm{H}_{2}$. Feed composition: $500 \mathrm{ppm} \mathrm{NO}, 520 \mathrm{ppm} \mathrm{NH}_{3}$, 5\% $\mathrm{O}_{2}, 0-1500 \mathrm{ppm}_{2}$, and $\mathrm{N}_{2}$ balance. GHSV: $150,000 \mathrm{~h}^{-1}$. 


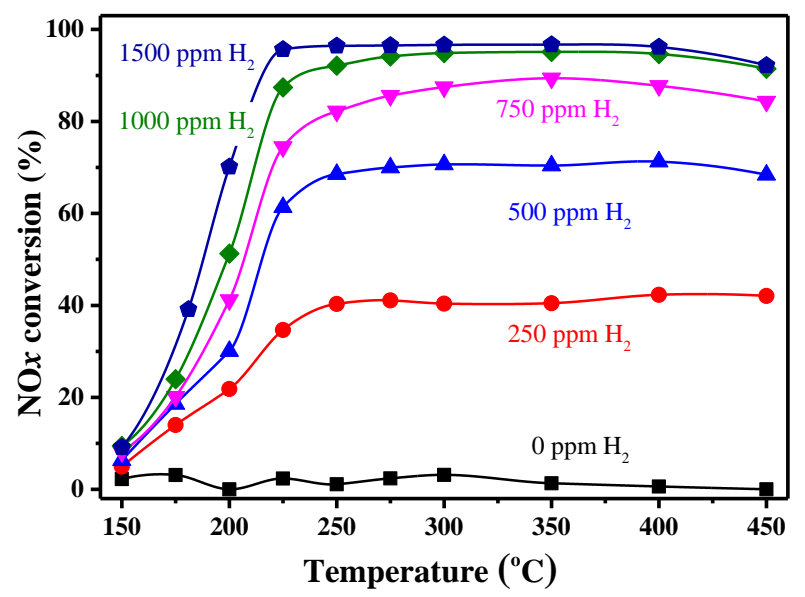

Figure S3. NOx conversion over $\mathrm{Ag} / \mathrm{Al}_{2} \mathrm{O}_{3}$ during $\mathrm{H}_{2}-\mathrm{NH}_{3}-\mathrm{SCR}$ in the presence of $\mathrm{H}_{2} \mathrm{O}$.

Feed composition: 500 ppm NO, 520 ppm $\mathrm{NH}_{3}, 5 \% \mathrm{O}_{2}, 0-1500 \mathrm{ppm} \mathrm{H}_{2}, 2 \% \mathrm{H}_{2} \mathrm{O}$, and $\mathrm{N}_{2}$ balance. GHSV: $150,000 \mathrm{~h}^{-1}$. 


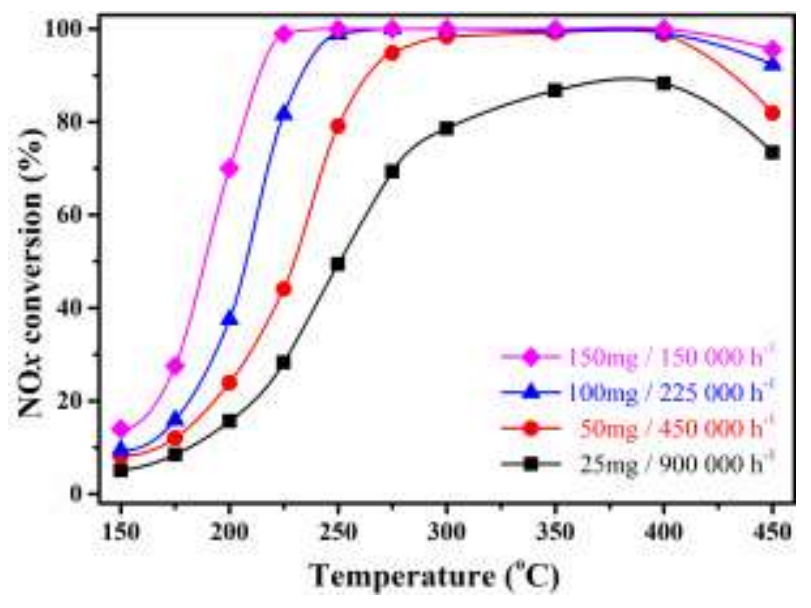

Figure S4. $\mathrm{NO} x$ conversion over $\mathrm{Ag} / \mathrm{Al}_{2} \mathrm{O}_{3}$ during $\mathrm{H}_{2}-\mathrm{NH}_{3}-\mathrm{SCR}$ under different GHSV.

Feed composition: 500 ppm NO, $520 \mathrm{ppm} \mathrm{NH}_{3}, 5 \% \mathrm{O}_{2}, 1500 \mathrm{ppm} \mathrm{H}_{2}$, and $\mathrm{N}_{2}$ balance. 


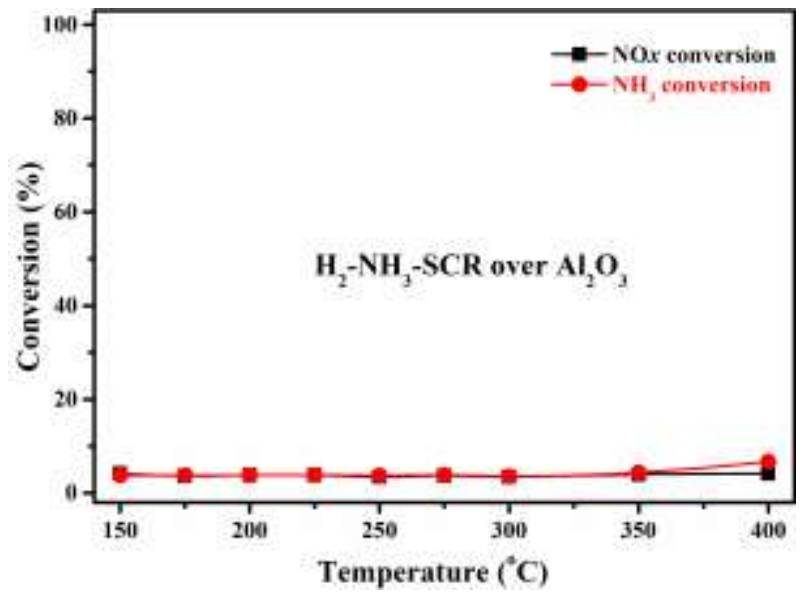

Figure S5. $\mathrm{NOx}$ and $\mathrm{NH}_{3}$ conversions over $\mathrm{Al}_{2} \mathrm{O}_{3}$ during $\mathrm{H}_{2}-\mathrm{NH}_{3}-\mathrm{SCR}$. Feed composition: 500 ppm NO, 520 ppm $\mathrm{NH}_{3}, 5 \% \mathrm{O}_{2}, 1500 \mathrm{ppm} \mathrm{H}_{2}$, and $\mathrm{N}_{2}$ balance. GHSV: $150,000 \mathrm{~h}^{-1}$ 

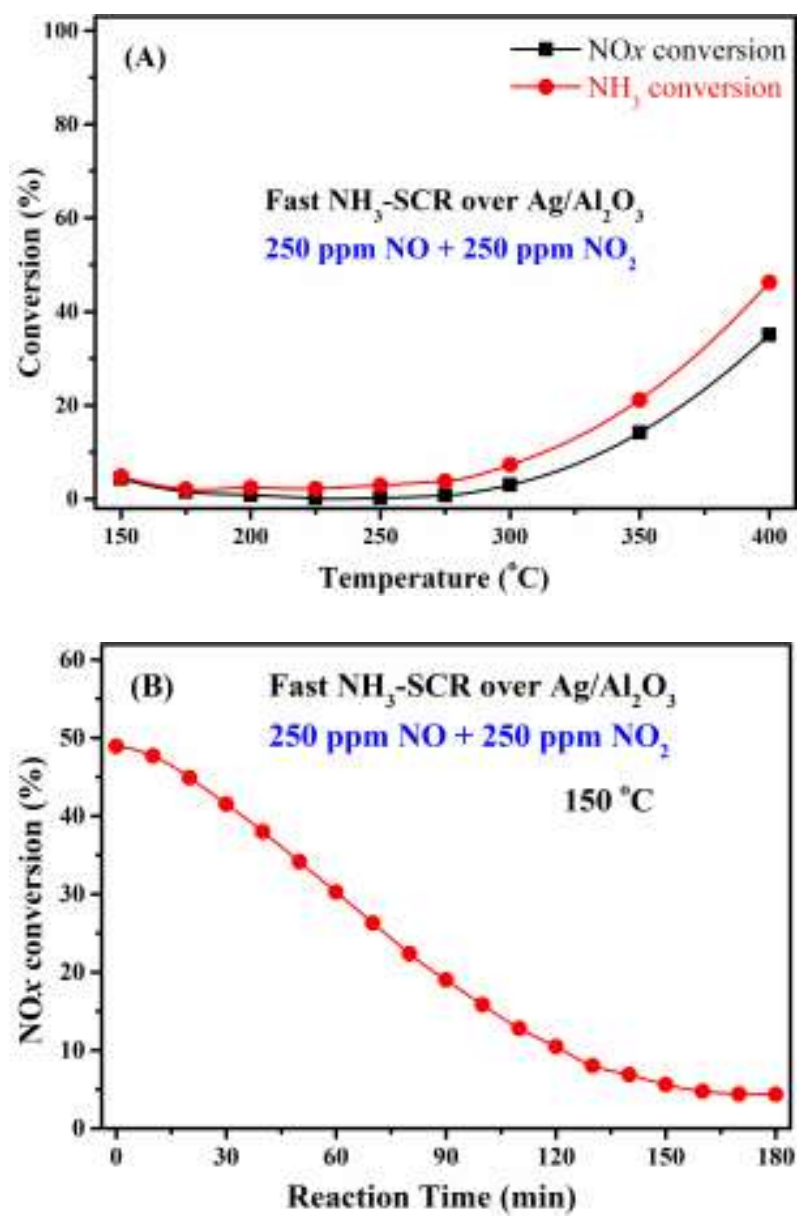

Figure S6. $\mathrm{NO} x$ and $\mathrm{NH}_{3}$ conversions over $\mathrm{Ag} / \mathrm{Al}_{2} \mathrm{O}_{3}$ during fast $\mathrm{NH}_{3}-\mathrm{SCR}(\mathrm{A})$ and NO $x$ conversion at $150{ }^{\circ} \mathrm{C}$ (B). Feed composition: 250 ppm NO, 250 ppm NO 2,520 ppm $\mathrm{NH}_{3}, 5 \% \mathrm{O}_{2}$, and $\mathrm{N}_{2}$ balance. GHSV: $150,000 \mathrm{~h}^{-1}$.

As shown in the Figure $\mathrm{S} 6 \mathrm{~B}$, the $\mathrm{Ag} / \mathrm{Al}_{2} \mathrm{O}_{3}$ catalyst was gradually deactivated at 150 ${ }^{\circ} \mathrm{C}$ during the fast $\mathrm{NH}_{3}-\mathrm{SCR}$. Therefore, the NOx conversion was measured at $150{ }^{\circ} \mathrm{C}$ for 180 min until the reaction reached a steady state. Afterward, the experiment was further performed at each temperature point for $40 \mathrm{~min}$ because the reaction reached a steady state more quickly at a higher temperature. Besides, other activity tests were performed at each temperature point for 40 min because those reactions reached a steady state more quickly. 


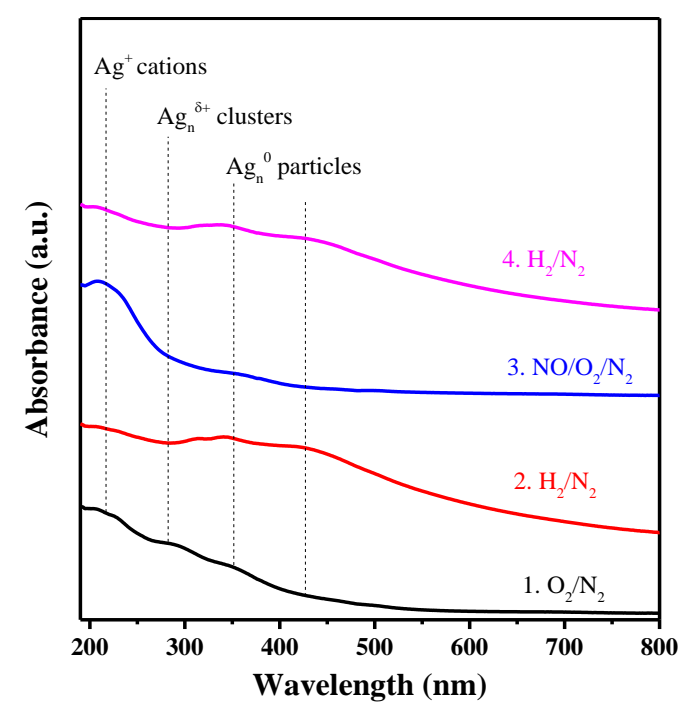

Figure S7. UV-vis spectra of $\mathrm{Ag} / \mathrm{Al}_{2} \mathrm{O}_{3}$ catalyst pretreated in $\mathrm{O}_{2} / \mathrm{N}_{2}$ (a), $\mathrm{H}_{2} / \mathrm{N}_{2}$ (b), $\mathrm{NO} / \mathrm{O}_{2} / \mathrm{N}_{2}$ (c), and $\mathrm{H}_{2} / \mathrm{N}_{2}$ (d) at $200{ }^{\circ} \mathrm{C}$ for 1 hour, respectively. Feed composition: 500 ppm NO, 1500 ppm $\mathrm{H}_{2}, 5 \% \mathrm{O}_{2}$, and $\mathrm{N}_{2}$ balance.

Figure S7 shows the UV-vis spectra of $\mathrm{Ag} / \mathrm{Al}_{2} \mathrm{O}_{3}$ catalyst pretreated in different atmosphere. Four adsorption peaks $(220,290,350$, and $425 \mathrm{~nm})$ were observed on the $\mathrm{Ag} / \mathrm{Al}_{2} \mathrm{O}_{3}$, and they were attributed to dispersed $\mathrm{Ag}$ cations $\left(\mathrm{Ag}^{+}, 220 \mathrm{~nm}\right)$, oxidized $\mathrm{Ag}$ clusters $\left(\operatorname{Ag}_{n}{ }^{\delta+}, 290 \mathrm{~nm}\right)$, and metallic $\mathrm{Ag}$ particles $\left(\operatorname{Ag}_{\mathrm{n}}{ }^{0}, 350\right.$ and $\left.425 \mathrm{~nm}\right)$. On the fresh sample, dispersed $\mathrm{Ag}$ cations were predominant, and $\mathrm{Ag}_{\mathrm{n}}{ }^{\delta+}$ and $\mathrm{Ag}_{\mathrm{n}}{ }^{0}$ were also observed. After exposure to $\mathrm{H}_{2}$, the oxidized silver species were reduced and thus increased the amount of metallic silver species. Afterward, the metallic silver species were converted to oxidized species in a flow of $\mathrm{NO}+\mathrm{O}_{2}$, possibly due to the formation of $\mathrm{AgNO}_{3}$. Moreover, the oxidized silver species were further converted to metallic silver species in a flow of $\mathrm{H}_{2} / \mathrm{N}_{2}$. Therefore, metallic silver species catalytically oxidized $\mathrm{NO}$ to produce nitrates, and $\mathrm{H}_{2}$ reduced the oxidized silver species, thus completing the redox cycle for the oxidized and reduced states of Ag species. 

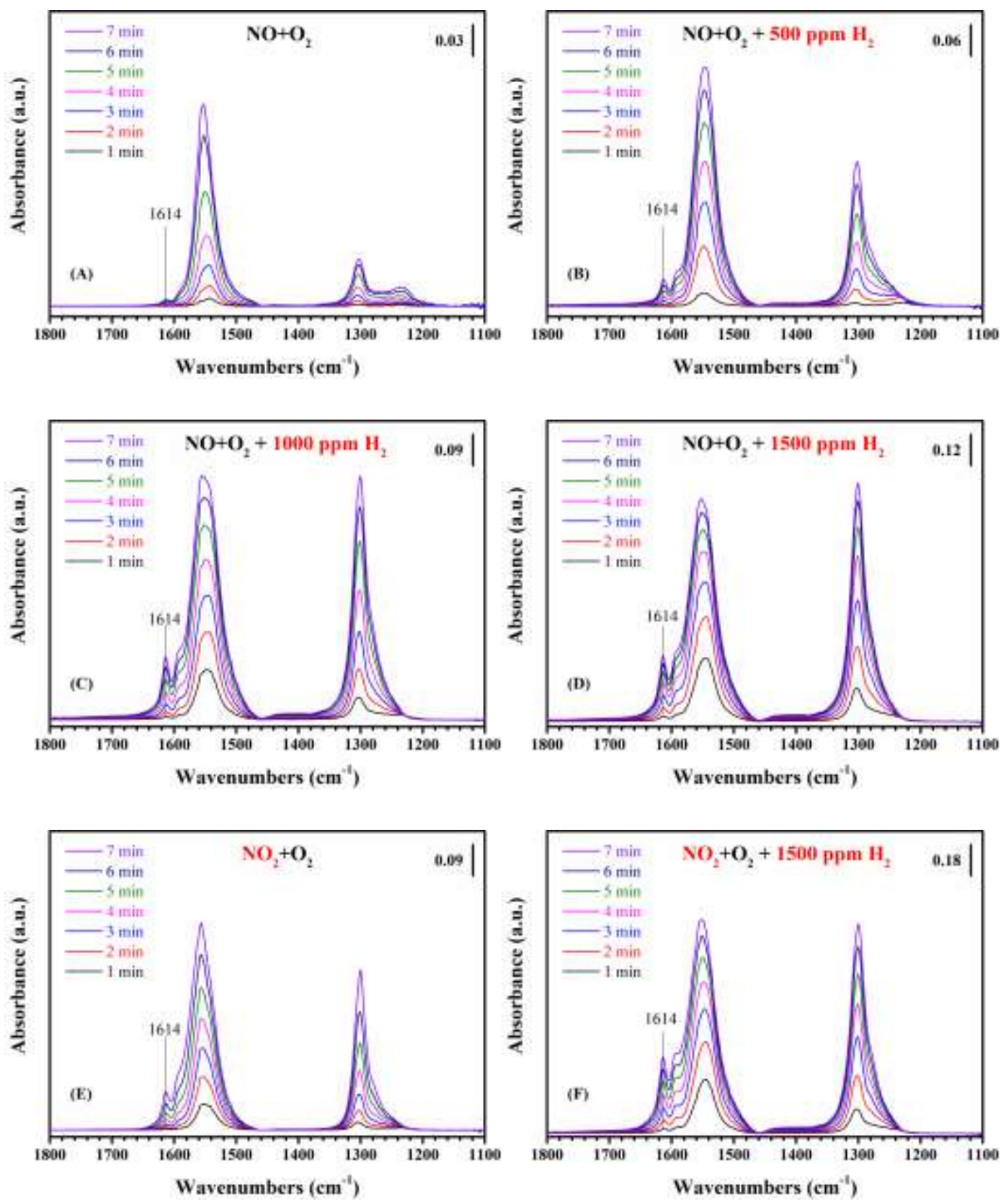

Figure S8. The DRIFTS spectra of adsorbed nitrate species over $\mathrm{Ag} / \mathrm{Al}_{2} \mathrm{O}_{3}$ after exposure to a flow of $\mathrm{H}_{2}+\mathrm{NO}+\mathrm{O}_{2}$ or $\mathrm{H}_{2}+\mathrm{NO}_{2}+\mathrm{O}_{2}$ with different amount of $\mathrm{H}_{2}$. Feed composition: 500 ppm $\mathrm{NO}$ (or $\mathrm{NO}_{2}$ ), $5 \% \mathrm{O}_{2}, 0-1500 \mathrm{ppm} \mathrm{H}_{2}, \mathrm{~N}_{2}$ balance, $200{ }^{\circ} \mathrm{C}$. 


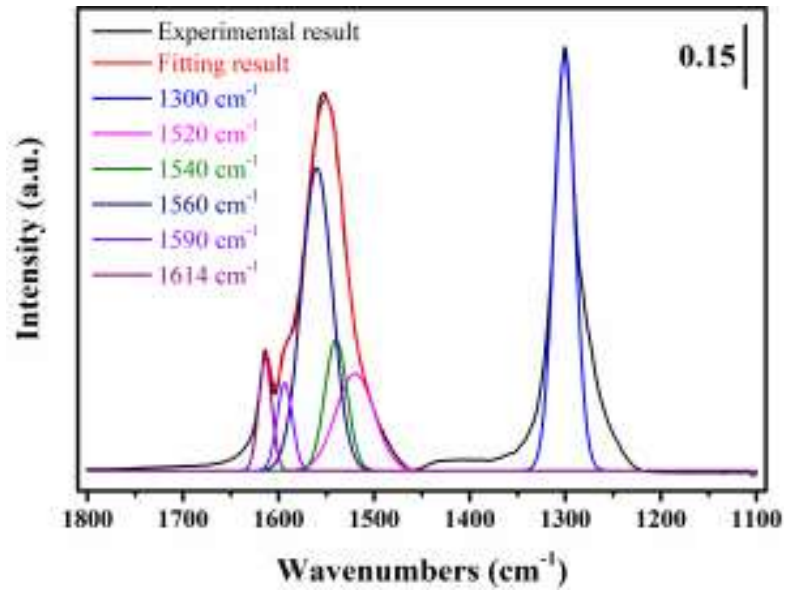

Figure S9. The deconvolution and curve fitting results for DRIFTS spectra in Figure 6 and S8. 

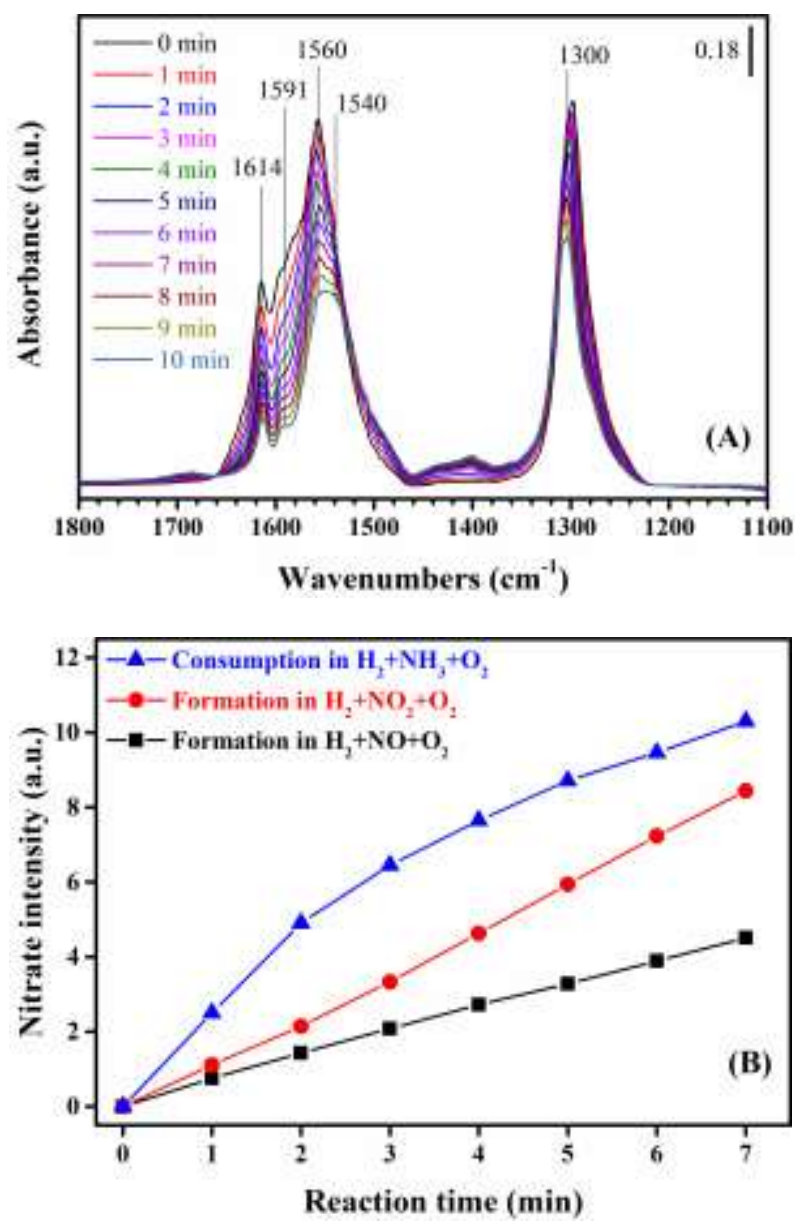

Figure S10. Reactivity of nitrate species toward $\mathrm{H}_{2}+\mathrm{NH}_{3}+\mathrm{O}_{2}$ over $\mathrm{Ag} / \mathrm{Al}_{2} \mathrm{O}_{3}$ at $200{ }^{\circ} \mathrm{C}$ (A). Comparison of the formation rate of bridge nitrate $\left(1614 \mathrm{~cm}^{-1}\right)$ in a flow of $\mathrm{H}_{2}+\mathrm{NO}+\mathrm{O}_{2}$ or $\mathrm{H}_{2}+\mathrm{NO}_{2}+\mathrm{O}_{2}$ and the consumption rate of bridge nitrate in a flow of $\mathrm{H}_{2}+\mathrm{NH}_{3}+\mathrm{O}_{2}$ over $\mathrm{Ag} / \mathrm{Al}_{2} \mathrm{O}_{3}(\mathrm{~B})$. 

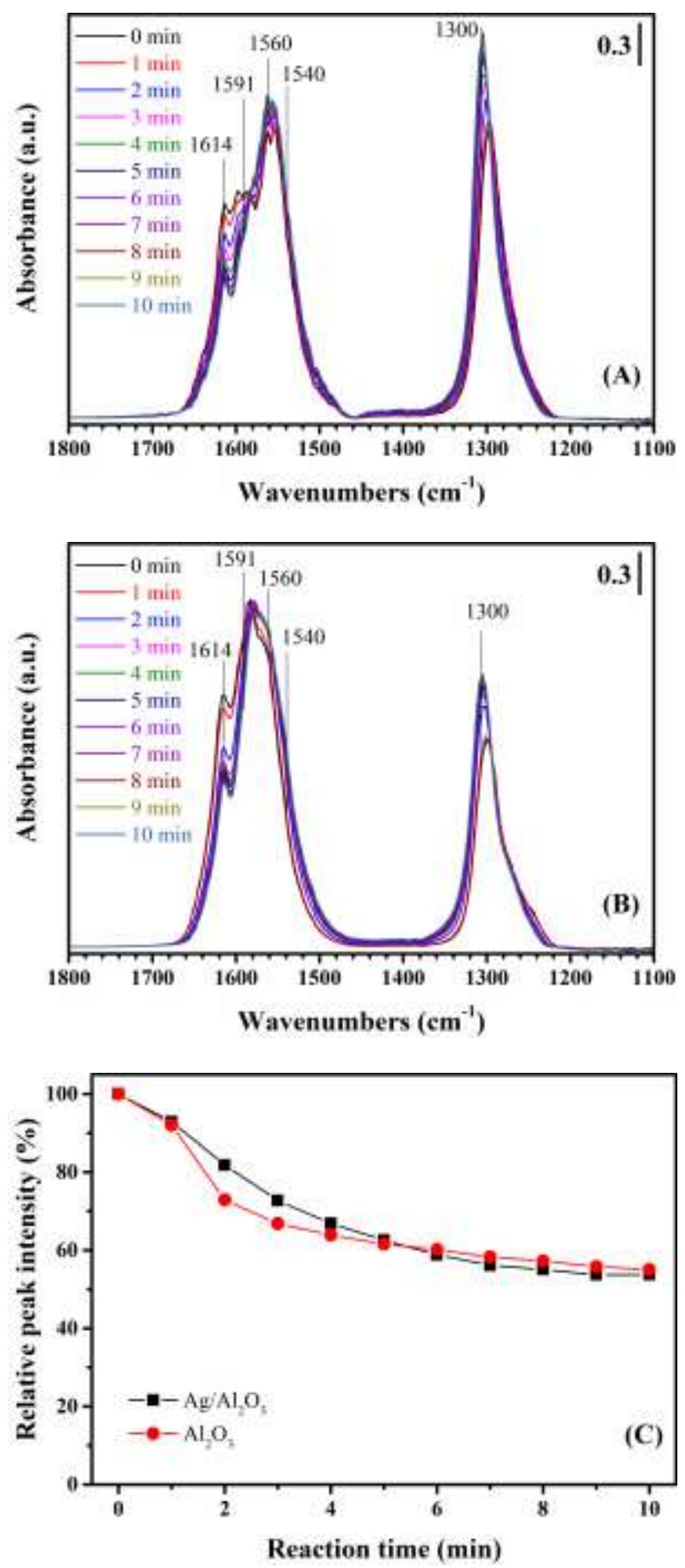

Figure S11. Reactivity of nitrate species toward $\mathrm{NH}_{3}+\mathrm{O}_{2}$ over $\mathrm{Ag} / \mathrm{Al}_{2} \mathrm{O}_{3}(\mathrm{~A})$ and $\mathrm{Al}_{2} \mathrm{O}_{3}$

(B) at $200{ }^{\circ} \mathrm{C}$. Comparison of the consumption rate of bridge nitrate $\left(1614 \mathrm{~cm}^{-1}\right)$ over $\mathrm{Ag} / \mathrm{Al}_{2} \mathrm{O}_{3}$ and $\mathrm{Al}_{2} \mathrm{O}_{3}(\mathrm{C})$. 


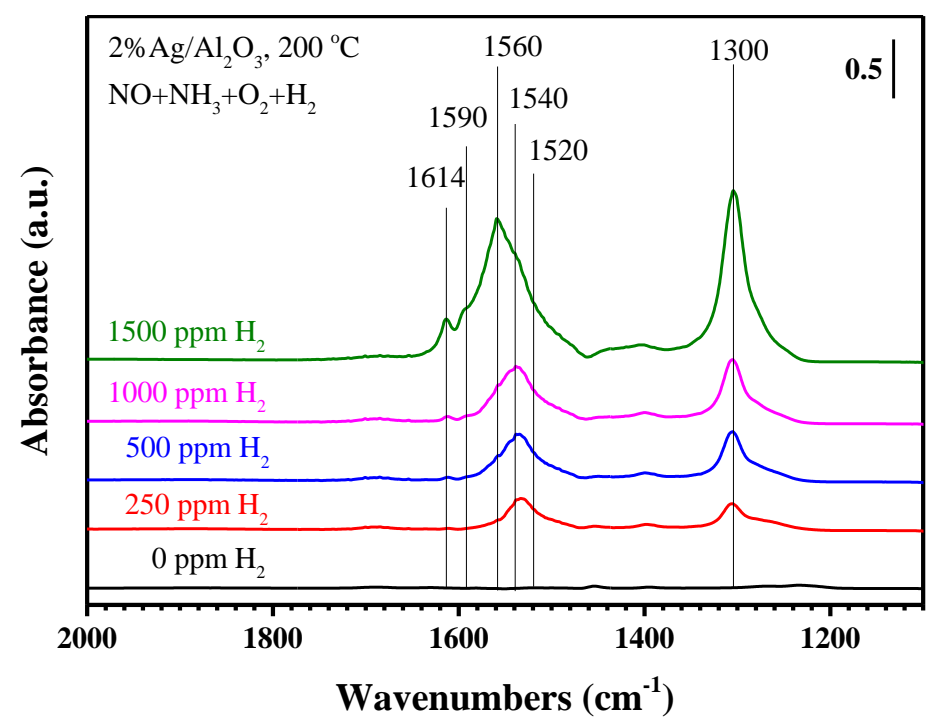

Figure S12. In situ DRIFTS of $\mathrm{H}_{2}-\mathrm{NH}_{3}-\mathrm{SCR}$ over $\mathrm{Ag} / \mathrm{Al}_{2} \mathrm{O}_{3}$ with different concentration of $\mathrm{H}_{2}$. Feed composition: 500 ppm NO, 500 ppm $\mathrm{NH}_{3}, 5 \% \mathrm{O}_{2}, 0-1500$ ppm $\mathrm{H}_{2}, \mathrm{~N}_{2}$ balance, $200{ }^{\circ} \mathrm{C}$.

Figure $\mathrm{S} 12$ shows in situ DRIFTS of the $\mathrm{H}_{2}-\mathrm{NH}_{3}-\mathrm{SCR}$ over $\mathrm{Ag} / \mathrm{Al}_{2} \mathrm{O}_{3}$ with different amount of $\mathrm{H}_{2}$ at $200{ }^{\circ} \mathrm{C}$. In this experiment, bridging nitrates $\left(1614 \mathrm{~cm}^{-1}\right)$, bidentate nitrates $\left(1590 \mathrm{~cm}^{-1}\right)$, and monodentate nitrates $\left(1560,1540,1520\right.$, and $\left.1300 \mathrm{~cm}^{-1}\right)$ were observed on the surface of catalyst. Adsorbed $\mathrm{NH}_{3}$ species was not observed possibly due to its low intensity (as shown in Figure 7). As the $\mathrm{H}_{2}$ concentration increased, the amount of adsorbed nitrates gradually increased. Notably, the reactive nitrate species (bridging nitrate and bidentate nitrate) were only observed when a high concentration of $\mathrm{H}_{2}$ (1500 ppm) was employed. As demonstrated in Figure 6, the formation rate of nitrate species on the $\mathrm{Ag} / \mathrm{Al}_{2} \mathrm{O}_{3}$ was determined by the $\mathrm{H}_{2}$ concentration. During the $\mathrm{H}_{2}-\mathrm{NH}_{3}-\mathrm{SCR}$ reaction with low concentration of $\mathrm{H}_{2}(\leq 1000 \mathrm{ppm})$, the formation of reactive nitrates was slower than its further reaction with $\mathrm{NH}_{3}$ species, thus resulting in the absence of these reactive nitrate species. When the $\mathrm{H}_{2}$ concentration was rather high 
(1500 ppm), the formation of reactive nitrates was fast enough and thus resulted in the accumulation of these species. This experiment further confirmed that the formation of reactive nitrates was the rate-determining step for the $\mathrm{H}_{2}-\mathrm{NH}_{3}-\mathrm{SCR}$ reaction. 